\title{
Corrigendum: Toll-like receptor 5 recognizes a conserved site on flagellin required for protofilament formation and bacterial motility
}

Kelly D Smith, Erica Andersen-Nissen, Fumitaka Hayashi, Katie Strobe, Molly A Bergman, Sara L Rassoulian Barrett, Brad T Cookson \& Alan Aderem

Nature Immunology 4, 1247-1253 (2003).

The authors regret neglecting to cite the paper by Mizel, S.B., West, A.P. \& Hantgan, R.R. Identification of a sequence in human toll-like receptor 5

required for the binding of Gram-negative flagellin. J. Biol. Chem. 278, 23624-23629 (2003) on page 1247, second paragraph, last sentence. 